\title{
Genotipagem e Antibiograma de Isolados de Campylobacter spp. Procedentes de Amostras Clínicas e de Alimentos do Sul do Brasil
}

Thalyta Marina Benetti (I), Wanda Moscalewski Abrahão (III,II), Tereza Cristina Rocha Moreira Oliveira (I)

(I) UEL - Universidade Estadual de Londrina (Rod. Celso Garcia Cid (PR 445), Km 380 - Caixa Postal 10.011, Londrina- PR), (II) UFPR - Universidade Federal do Paraná ( Av. Lothário Meissner, 632, CEP: 80210-170, Jardim Botânico, Curitiba- PR), (III) LACEN-PR - Laboratório Central do Estado do Paraná (Rua Amintas de Barros, 816 Bairro Alto da XV - Curitiba/PR CEP: 80.060-200)

\section{Resumo}

As aves têm sido reportadas mundialmente como os principais responsáveis por infecções de Campylobacter em humanos, embora outros reservatórios incluindo fontes de água contaminada, bem como animais domésticos e animais selvagens também estão envolvidos. No Brasil, são escassos os estudos sobre a ecologia, transmissibilidade e diversidade gênica de Campylobacter isolado de alimentos e humanos. O objetivo do presente estudo foi verificar a diversidade genética e sensibilidade aos antimicrobianos de cepas de Campylobacter spp. isoladas de alimentos e de material biológico humano, com a finalidade de estabelecer a ligação entre os genótipos e a origem dos isolados no mesmo período de tempo. Para a genotipagem utilizou-se a técnica semi-automatizada Diversilab ${ }^{\circledR}$ (Biomerieux) que se baseia na técnica de sequências repetitivas de DNA (REP-PCR). O perfil de sensibilidade a antimicrobianos foi realizado pela técnica de disco difusão de Kirby-Bauer. Um total de 43 cepas de Campylobacter isoladas entre 2006 a 2011 de carcaças de frango (produzidas nos estado da região Sul do Brasil) e de fezes humanas (de diferentes municípios do Estado do Paraná) foram avaliadas. Doze antibióticos foram testados, de acordo com recomendações do Clinical and Laboratory Standards Institute. Vinte e três genótipos distribuídos em 14 grupos foram obtidos na análise de 43 isolados de Campylobacter estudados. Cepas genotipicamente indistinguíveis foram identificadas entre 
as cepas isoladas de alimentos e de fezes humanas coletadas no ano de 2011. A semelhança genotípica em um isolado de carcaça de frango e de dois isolados de fezes humanas sugeriram uma provável correlação epidemiológica, que também foi verificada pela sensibilidade aos 12 antimicrobianos testados. Esses isolados foram coletados em julho de 2011, na região norte do Estado Paraná. Considerando que informações adicionais são necessárias, não pode ser afirmado que os isolados analisados estão envolvidos em um evento de surto. Os resultados do presente estudo identificaram correlação entre a similaridade genética e o perfil de sensibilidade à antimicrobianos de alguns isolados analisados, dados estes que poderão facilitar o desenvolvimento de estratégias de intervenção para o controle e prevenção da campilobacteriose.

Palavras-Chave: Campylobacter spp., genotipagem, antibiograma, carcaça de frango resfriada, fezes humanas

\section{Agência de Fomento:}

